Rasmus Chr. Elling er MA i Mellemøststudier og Ph.d. i Iranstudier. Han er pt. adjunkt ved Københavns Universitets Institut for Tværkulturelle og Regionale Studier. Han udgav i 2013 Minorities in Iran: Nationalism and Ethnicity after Khomeini og beskæftiger sig med by-studier, historie og sociologi.

Nøgleord: By, olie, nostalgi, Iran, ressource.

\title{
OLIEBYEN MIDT I EN JAZZTID Nostalgi, magi og det moderne i Abadan
}

Vi hører ofte, at olieforekomst er en velsignelse pakket ind i en forbandelse, der medfører rigdom for nogle og elendighed for mange: Det sorte guld for eliterne er 'djævlens ekskrement' for masserne. Olien skaber forurening, avler vold og korruption, den nærer diktaturer og kvæler demokratiske kræfter. For at nuancere denne gængse historie, tager nærværende artikel udgangspunkt i det helt særlige, moderne bysamfund, som olien formede, da den i det 20. århundrede tilvejebragte Abadan midt i ørkenen i Iran. Hvordan mindes abadanierne i dag med nostalgi byens florissante periode, og hvordan hænger denne nostalgi sammen med oliens „magiske kraft“?

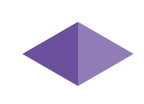

„Det var med olien her fra at europæerne kunne oplyse deres gader“, siger min vært imens hans gamle, rustne bil kravler over en uoplyst, støvet og hullet vej. „Uden Abadan havde der stadig været mørke i Europa!“. Vi er i Khuzestan-provinsen i det sydvestlige Iran ved grænsen til Irak, hvor floderne Eufrat, Tigris og Karun flyder sammen og ud i den Persiske Golf. Engang var Abadan hjemsted for verdens største og vigtigste olieraffinaderi. Rundt om raffinaderiet lå en af Mellemøstens mest moderne og mangfoldige byer. I dag er Abadan blot en skygge af sig selv, og indbyggerne dyrker fortiden med en nostalgi, der flyder tykt i byens kulturelle årer. 
Min motivation for at skrive om denne nostalgi er delvist personlig, delvist teoretisk. Da jeg i forbindelse med det internationale forskningsprojekt Urban Violence in the Middle East i 2011 drog til Abadan for første gang ville jeg opstøve lokalhistorier om byens voldelige fortid under det britisk-ejede olieselskab, der indtil 1951 styrede Abadan som en slags koloni. ${ }^{1}$ Mit historiske projekt var baseret på en post-kolonial kritik af oliens rolle i moderniseringen af Mellemøsten som funderet i en imperialisme, der skaber ressourceafhængige autoritære rentierstater, og i en kapitalisme, der undertrykker arbejderbevægelser og umuliggør social retfærdighed. ${ }^{2}$ Men da jeg besøgte Abadan, var det en anden forståelse af historien, jeg mødte: Den ene abadani efter den anden ville meget hellere fortælle kære minder om fredelig sameksistens, kulturel blomstring, materiel velstand, velfærd og trivsel med olieindustrien som drivkraft. Der var en konflikt mellem den voldelige fortid, jeg kunne afdække i de historiske kilder, og den nutidige romantisering af fortiden, jeg oplevede i Abadan. Denne konflikt rettede min opmærksomhed mod nostalgi som en vigtig komponent i dannelsen af en abadani populærkultur og selvopfattelse.

Litteraturen viser, at al nostalgi ikke nødvendigvis er passiv, reaktionær og regressiv, men at længslen efter tider og steder indebærer en potentiel kreativitet, handlekraft og fremsynethed. ${ }^{3}$ Idet den ihukomne fortid altid skal filtreres, håndplukkes, arrangeres og genfortælles er nostalgi ikke blot konservering men også nyskabelse. Snarere end anti-moderne eller umoderne, så gør nostalgien, som et modernitetens fænomen, mennesker i stand til at kritisere 'det moderne'. I sin 'nostalgiens sociologi' anskuer Fred Davis fænomenet i psykologiske termer: Han forklarer at ligesom overgangsfaser i et individs liv, så kan uforudsigelige historiske hændelser og abrupte omvæltninger i et samfund også fremprovokere angst og udløse nostalgi. Nostalgien, skriver Davis, „genfortryller, om ikke andet indtil den historiske forandrings ustandselige processer udtømmer den fortid, der for en stund tilbød ly fra en foruroligende og i sidste ende ubønhørlig fremtid“.4 Nostalgikeren forsøger, ifølge Svetlana Boym, ,at omdanne historie til privat eller kollektiv mytologi, at genbesøge tid som var det rum, at modsætte sig tidens uigenkaldelighed, som plager den menneskelige tilstand“. ${ }^{5}$

1 Urban Violence in the Middle East var et engelsk-tysk forskningsprojekt, der under Dr. Nelida Fuccaro på SOAS, University of London, og Dr. Ulrike Freitag, Zentrum Moderner Orient, Berlin, i perioden 2011-2013 undersøgte sammenhængen mellem kollektiv vold og offentlige byrum i Mellemøstens moderne historie. Se: Freitag et al 2015, Fuccaro 2015 og hjemmesiden http:// www. soas.ac.uk/uvme/.

2 I forhold til Abadan er nogle af disse emner før blevet behandlet af Bayat 2007, Crinson 1997, Cronin 2010 og Ehsani 2003 - sidstnævnte har især været en stor inspiration. Se desuden: Elling 2015a og 2015b.

3 Se fx Boym 2007, Davis 1979, Gross 2000.

4 Davis 1979: 116. Alle citater $i$ artiklen er oversat af forfatteren.

5 Boym 2007: 8. 
Som vi vil se i denne artikel, så har Abadan de sidste fire årtier gennemgået hændelser, der kan foranledige en trang til genfortryllelse og et behov for en kollektiv mytologi. Men snarere end en psykisk reaktion så kan nostalgien også anskues som et fleksibelt og omstridt element i kulturelle selvopfattelser. I Abadans tilfælde bliver spørgsmålet: Hvordan hænger disse selvopfattelser sammen med olien?

Den gængse litteratur om olieproducerende lande, især om Mellemøsten, har en tendens til at behandle olien udelukkende som makroøkonomisk og geopolitisk faktor. Men i tråd med dette temanummer er en række forskere begyndt at interessere sig for oliens sociale og kulturelle liv. De foreslår at vi giver olien agens som et fænomen på grænsen mellem natur og menneske, der besidder en iboende evne til at forme og præge nationer, samfundsklasser, individer, myter og følelser. ${ }^{6}$ Fernando Coronil har fx forsket i hvordan venezuelanske præsidenter skabte forestillingen om at oliens „magiske kraft“ kan „fremtrylle“ en moderne nation, og hvordan borgerne til gengæld feticherede olien som et mirakel. ${ }^{7}$ I den mellemøstlige kontekst har min kollega Nelida Fuccaro været banebryder for 'oliens etnografi'. Hun foreslår at man især igennem byhistorie kan studere oliens evne til at forme og forvandle kulturlandskaber og påvirke kollektiv erindring. ${ }^{8} \mathrm{Med}$ udgangspunkt i dette forslag låner jeg i denne artikel Coronils ide om oliens ,,magiske kraft“ til at beskrive de forestillinger som Abadans korte men begivenhedsrige historie har frembragt igennem tilblivelsen af en helt særlig abadani kultur.

Jeg har i mit arbejde med Abadan primært trukket på kilder fra BP Archives i Coventry, der opbevarer materiale fra Anglo-Persian Oil Company (siden Anglo-Iranian Oil Company, i denne artikel kaldt 'selskabet'), samt fra britiske og iranske statsarkiver og aviser. Men her vil jeg i stedet fokusere på erindringer, selvbiografier og populærkulturelle bøger, som Abadans amatørhistorikere igennem de sidste to årtier har udgivet på persisk i Iran, og som jeg for nemheds skyld vil kalde nostalgibøgerne. Derudover vil jeg trække på en række kvalitative, løst strukturerede interviews jeg gennemførte i Abadan i 2012 og 2013 med bl.a. unge studerende, midaldrende erhvervsdrivende og lokalpolitikere samt pensionerede og tidligere ansatte i olieindustrien. Som det vil fremgå er netop kilderne og interviewene omdrejningspunktet for artiklen: Det olieprodukt, så at sige, jeg vil analysere, for at forstå en naturressources magiske kraft i et samfund. Men først skal vi se hvordan olien har fungeret som katalysator for menneskelig socialitet i Abadans historie.

6 Se: Davis \& Gavrielides 1991, Limbert 2010, Salas 2009, Vitalis 2007 og Watts 2001. Mitchell 2011 er et forsøg på at placere olien centralt i den globale fortælling om demokrati og mangel på demokrati. Se desuden Ferguson 1999 for en innovativ tilgang til kobberindustriens sociale liv $i$ Zambia.

7 Coronil 1997.

8 Fuccaro 2013a og 2013b. Samme tidsskrift indeholder en række spændende artikler om olieurbanitet, der har inspireret denne artikel, herunder især Alissa 2013. 


\section{Fortidens abrupte fremskridt}

Når man flyver ind over Abadan om natten fremstår raffinaderiet som umiskendeligt omdrejningspunkt for den by, olietårnenes flammer med jævne mellemrum oplyser. Men for lige over et hundrede år siden var den lille ø kun beboet af en håndfuld stammer, der levede i mudderhytter og dyrkede daddelpalmer, fiskede og småhandlede med nabobyerne. Selvom olien bogstavelig talt sivede op af jorden og ind i folks hjem overalt i Khuzestan-provinsen, så var der nok ingen, der havde gættet hvor stor en rolle den på få år ville indtage. Oliens ubemærkede nærvær skulle snart komme til at stå i kontrast til dens altafgørende tilstedeværelse i de mileskridt, regionen tog i det 20. århundrede.

I modsætning til Irans persiske hjerteland var Abadan og den sydlige del af Khuzestan-provinsen et overvejende arabisk område, og i starten af 1900-tallet herskede den lokale sheik mere eller mindre uafhængigt af shahen i Teheran. Shahen - som næppe heller drømte om råstoffets forestående globale gennembrud - solgte i 1901 retten til at søge efter olie til Sir William Knox D’Arcy, en risikovillig millionær i London. D’Arcys udforskningshold knoklede flere år i det ufremkommelige grænseland, hvor de ikke kun var oppe imod de højeste temperaturer i verden, men også truet af landevejsrøvere og krigeriske stammer. D’Arcy mistede en formue og havde egentlig opgivet da hans chefgeolog blev vækket tidligt om morgenen den 26. maj 1908 af en dyb rumlen under teltlejren nær Masjed Soleyman nord for Abadan: Olien sprøjtede op af en prøveboring. På et kontor i London så man på et kort, og valgte Abadan som stedet hvor man ville raffinere og udskibe olien. Den lokale sheik tog gladelig imod den pludselige interesse for hans domæner og fremlejede sin stammes jord på den mudrede Abadan- $\varnothing$ til briterne. Med dampskibe, muldyr, dromedarer, britiske ingeniører og indiske arbejdere lykkedes det imod alle odds at bygge et raffinaderi, der fra 1913 kunne eksportere olie til et verdensmarked i voldsom vækst. Som startskuddet til briternes såkaldte 'persiske eventyr' var selve grundlæggelsen af raffinaderiet den første fysiske materialisering af oliens magiske kraft i Abadan.

I begyndelsen boede arbejderne i telte udenfor den arabiske landsby men med olieindustriens fænomenale udvikling blev der hurtigt brug for at bygge en helt ny by.

Udover det komplette fravær af lokal infrastruktur var de britiske oliepionerers største klage at den lokale arbejdskraft hverken havde den fornødne tekniske kunnen eller industriel disciplin. I stedet importerede man arbejdere fra Indien, Kaukasus og Mesopotamien samt fra andre egne af Iran. Øverst i Abadans arbejdshierarki stod briterne og deres vestlige kollegaer. Til det tekniske og administrative arbejde samt til briternes husholdning benyttede man sig primært af indere, og derudover var det kristne armeniere og assyrer samt jøder, man stolede på. De muslimske iranere blev ansat i hierarkiets nederste lag, hvor de arbejdede 
med de hårdeste og farligste opgaver og levede under kummerlige forhold. Snart strømmede iranere fra hele landet til den før oversete udpost, der nu var et Klondyke. Olien forvandlede Abadan til en storby. Olieselskabet havde ingen erfaring med at skabe og styre samfund, men da mange af pionererne havde en fortid i Britisk Indien kunne de medbringe kolonialistiske idéer og praktisk viden om social ingeniørkunst til Abadan. Selvom Iran aldrig var en formel koloni havde olien alligevel bragt imperialismen ind i landet.

Rig af erfaringer fra Indien vidste briterne, at en multietnisk, overbefolket by udgør en sikkerhedstrussel. Ganske rigtigt var der fra begyndelsen småstridigheder mellem tilflytterne og de lokale, der målløse så til, imens deres hjemegn blev omdannet fra palmelunde til industriby. Så tidligt som 1920 gik indiske gæstearbejdere i strejke i protest mod dårlig behandling og lave lønninger, og det blev startskuddet til en lang og dramatisk arbejderbevægelseshistorie. Briterne slog brutalt ned på uro og selskabet indførte omfattende kontrol og overvågning. Men de iranske oliearbejdere havde nu lært hvordan man kunne tvinge selskabet til indrømmelser ved at lamme det mest følsomme led i den dyrebare produktionscyklus, nemlig raffinaderiet. I 1929 blev Abadan ramt af en strejke, der inspirerede en voksende iransk nationalistbevægelse. Olien havde således afstedkommet en ny form for politisk agens og bevidsthed, der i modstanden mod britisk imperialisme skulle få afgørende betydning for Irans politiske historie.

For at imødekomme truslen fra det samfund, man havde skabt, tyede selskabet til velafprøvede strategier for segregering. Man placerede de øverste i hierarkiet i bydelen Braim i den behagelige ende af Abadan-øen, hvor vindforholdene gjorde tropelivet udholdeligt og hvor briterne uforstyrret kunne dyrke deres kultur i bungalower, cricketklubber, haver og til te-selskaber. Her var de afskærmede fra de ikke-hvide i kraft af raffinaderiet, der fungerede som en gigantisk metallisk barriere midt på øen. På den anden side af raffinaderiet lå 'den indfødte by', der udover den gamle arabiske landsby, basar og havn nu også bestod af en hastigt voksende slum af blikskure. Med tiden indså selskabet, at slumkvarterernes overbefolkning, sygdomme og kriminalitet kunne skade olieproduktionen, så man importerede præfabrikerede barakker til oliearbejderne. Selskabet installerede i 1930erne gradvist kloakering og elektricitet, og man udbyggede vejnettet, den offentlige transport og sundhedsvæsnet, og med tiden også skoler, klubber, biografer og et universitet. I løbet af 1940erne byggede man nye kvarterer efter forbillede fra de amerikanske company towns, der havde domineret Midtvesten fra omkring århundredeskiftet. ${ }^{9}$ Man opførte rækkehuse med indlagt vand og siden med aircondition.

Det er fra kilderne tydeligt, at selskabet ikke brød sig om at skulle forestå denne byudvikling, og man forsøgte at få de iranske og britiske stater til at betale.

9 Se Dinius \& Vergara 2011. 


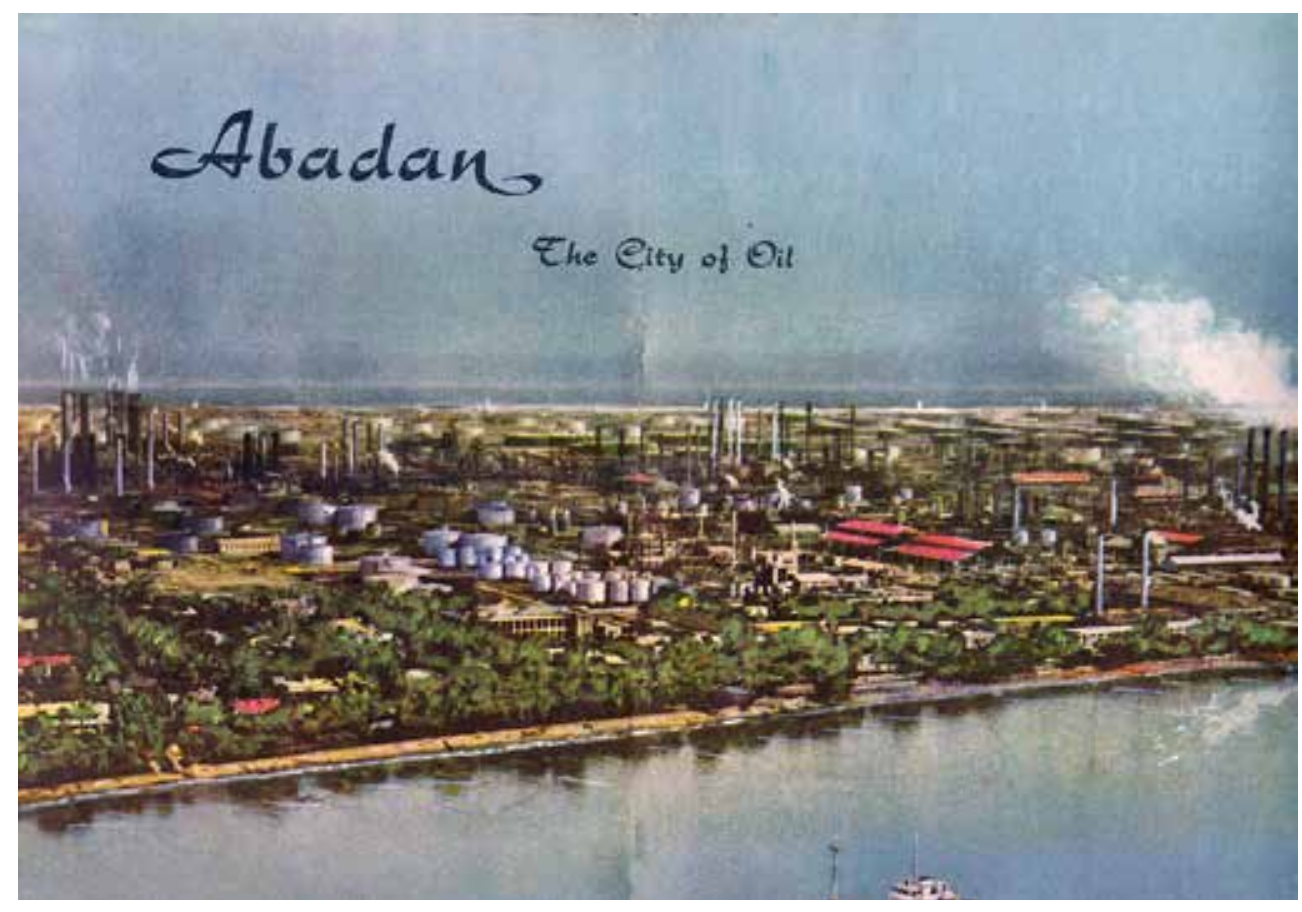

Fig. 1: Fra en publikation udgivet af den iranske stat i slutningen af 1950erne. Kilde: http:// commons.wikimedia.org/wiki/Category:Abadan\#mediaviewer/File:Abadan_the_city_of_Oil.jpg

Ansvaret endte dog i sidste ende hos selskabet, der til gengæld tillod sig at agere som den reelle magthaver i oliebyerne, der skød op i Khuzestan-provinsen. Med en konstant voksende indtægt blev selskabet til en stat i staten og Abadan fungerede som dets iranske hovedstad. Befolkningen forøgedes fra omkring $10.000 \mathrm{i}$ starten af 1920erne til 220.000 i 1951, og fra 1930erne begyndte iranerne at rykke fra nederste lag i arbejdshierarkiet op i det midterste. Olien havde tilvejebragt et klasseopdelt samfund men også en moderne velfærd og materiel velstand, der på det tidspunkt var uhørt i Iran (fig. 1).

I mellemtiden havde vestlige økonomiske og militære magter gjort olien til en af den moderne verdens strategisk vigtigste ressourcer. I 1913 skiftede den britiske flåde fra kul til olie, og det var bl.a. med Abadan-olie i tanken at briterne drev mod sejr i Første Verdenskrig. Med Winston Churchill som lobbyist blev den britiske stat selskabets største aktieejer, og nu var olien med til at ændre hele Mellemøsten: Nye stater blev skåret ud af det besejrede osmanniske imperium og i Iran gennemførte officeren Reza Khan et kup i 1921 med britisk hjælp. Efter at have konsolideret al magt indadtil begyndte han i 1925, nu som Reza Shah, at statuere sin magt udadtil - bl.a. ved at kræve et større stykke af den konstant voksende oliekage. Selskabet stod således overfor en mere selvsikker shah og en tiltagende arbejderbevægelse, og måtte med tiden give indrømmelser.

Men højere lønninger, øget social mobilitet og bedre velfærd kunne ikke dække over det grundlæggende uretfærdige i, at selskabet skattefrit tjente styrtende 
på Irans ressourcer imens vestlige magter fastsatte værdien af disse ressourcer. Arbejderne i Abadan var også udmærket klar over at termer som senior og junior employee stadig blot var metaforer for etnisk diskrimination i deres arbejdsliv og lokalsamfund. Anden Verdenskrig var for en stund med til at styrke selskabets fodfæste da den britiske hær besatte Sydiran og udskiftede shahen med hans søn, Mohammad-Reza Shah. Men allerede i 1946 blev Abadan igen ramt af omfattende strejker. Olien stod nu i centrum af al politisk diskussion og aktivitet i Iran. Båret af en folkebevægelse lykkedes det omsider den populære premierminister Mohammad Mosaddeq at nationalisere olien i 1951. Under dramatiske omstændigheder måtte briterne evakueres imens 'Abadankrisen' var på alles læber i Vesten. Men blot to år efter væltede CIA til gengæld Mosaddeq, hvilket gav shahen frie hænder til at føre sine autoritære ambitioner ud i livet. Hovedstolen af olieindtægterne var nu på iranske hænder, og med disse kunne shahen gennemtvinge en omfattende moderniseringsproces.

Abadan gik ind i en ny guldalder, og imens oliepriserne steg, voksede befolkningen til over 400.000. Det nye ideal var den amerikanske forstad, den arbejdende fader, den aktive men hjemmegående husmor og den sunde kernefamilie. Selskabets pr-afdeling i Abadan var med til at fremelske disse idealer, der også passede ind i Mohammad-Reza Shahs vision for et sekulariseret, vestliggjort Iran. Idealerne blev fremstillet som opnåelige takket være oliens mirakuløse tilstedeværelse - og selskabet, oliebrøndene, rørledningerne, raffinaderiet og arbejderne som katalysatorer for miraklet. Oliebyen var stadig hjem for mange vesterlændinge, men også for flere og flere kunstnere, filmmagere, forfattere, samfundskritikere, intellektuelle og unge politiske aktivister, der ikke ville indordne sig shahens vision.

Med revolutionen i 1978-79 måtte de sidste udlændinge forlade Abadan. Revolutionen havde rødder i hhv. den venstreradikalisme, man havde set i Abadan, og i den islamistiske retorik hvormed Ayatollah Khomeini kritiserede shahen som en tjener for vestlige interesser. Et vendepunkt, der radikaliserede oprøret mod shahen var faktisk en hændelse i Abadan: Den 19. august 1978 satte ukendte gerningsmænd ild til en propfyldt biograf, Cinema Rex. Mindst 500 omkom, og det diskuteres stadig om det var shahens eller Khomeinis folk, der stod bag. Under alle omstændigheder gik revolutionen i månederne efter branden ind i sin endelige fase, der kulminerede med shahens afsættelse og etableringen af en islamisk republik. Ligesom resten af Iran gennemgik Abadan en omfattende islamisering af offentligt rum og kultur. Sekulære, socialister og liberale blev drevet på flugt imens staten gennemførte en kampagne, der skulle udrydde al vestlig kulturimperialisme og moralsk fordærv. Netop som Khomeini havde konsolideret sin magt blev Iran i 1980 angrebet af Irak, bl.a. fordi Saddam Hussein drømte om at annektere de olierige områder omkring Abadan. 
I løbet af otte års blodig krig blev provinsen raseret. Abadan blev evakueret imens store dele af byen, herunder raffinaderiet, blev bombet af irakerne. Irans mest moderne by blev forvandlet til en gennemhullet spøgelsesby. Først efter krigens afslutning i 1988 var det muligt at genbefolke byen, men da havde mange abadanier slået rødder andetsteds. De, der vendte tilbage, og de mange nye tilflyttere, var ofte fattige med lavere uddannelse, og da staten valgte at bygge nye raffinaderier andetsteds genvandt Abadan aldrig sin status. Olien havde mistet sin magiske kraft og Abadans fremdrift var abrupt blevet afbrudt. Byen blev mere eller mindre glemt af magthaverne - men mindet om det gamle Abadan levede videre.

\section{Nostalgiens kronede dage}

Nostalgien slår enhver, der besøger Abadan i dag. Det er som om mange abadanier føler, at de skal undskylde for, hvad man som udenlandsk gæst ser, og i stedet fortælle om alt det, man kunne have oplevet for tredive, fyrre eller halvtreds år siden. En af mine informanter, en tidligere kaptajn på olieselskabets tankere, brugte således en hel dag på at vise mig Abadans forskellige bydele, museum og basar. For hvert sted vi besøgte fortalte kaptajnen om sine minder med stedet og de skikkelser, der frekventerede det før revolutionen: Den græske fotografs fine atelier hvor folk fik taget bryllupsbilleder, den jødiskejede kiosk ved runddelen, der solgte tidsskrifter fra udlandet, hotellet hvor oliefolk fra hele verden stimlede sammen i baren for at fortælle røverhistorier. Men især ét sted glæder kaptajnen sig til: En butik i basaren, der sælger solbriller, musik-CDer og fremkalder billeder. Her har kaptajnen nemlig forudbestilt en overraskelse til mig: Et tykt, indbundet fotoalbum proppet med prints af billeder fra gamle Abadan (fig. 2). Forhandleren har samlet billederne fra internettet, trykker dem og sælger dem på samme måde som med private fotoalbum.

I albummet er der billeder af swimmingpools, familiemiddage og picnics i det grønne, roningskonkurrencer, blomsterudstillinger og scener med børn, der bliver vaccineret af sygeplejersker. De fleste kvinder er uden slør og bærer nederdele, håret er sat som Audrey Hepburn eller Sofia Loren, og de smiler til kameraet. På de sort/hvide billeder er mændene i hat, jakkesæt og slips og på farvefotos har de trompetbukser, nedknappede skjorter med store flips, 70er-frisurer og overskæg. Gaderne er ikke overtrafikerede, og bilerne er amerikanske. Nogle steder ligner Abadan en køn forstad i efterkrigstidens Florida, den søvnige idyl kun forstyrret af det dampende raffinaderi i baggrunden. Og der er fornemt besøg i klubberne: Jazzlegenden Dizzy Gillespie poserer fx ved en reception i Abadan i 1956 med prinsesse Shams Pahlavi, shahens søster. Imens jeg bladrer igennem albummet stimler en gruppe lokale unge sammen og ser mig over skulderen i begejstring - 


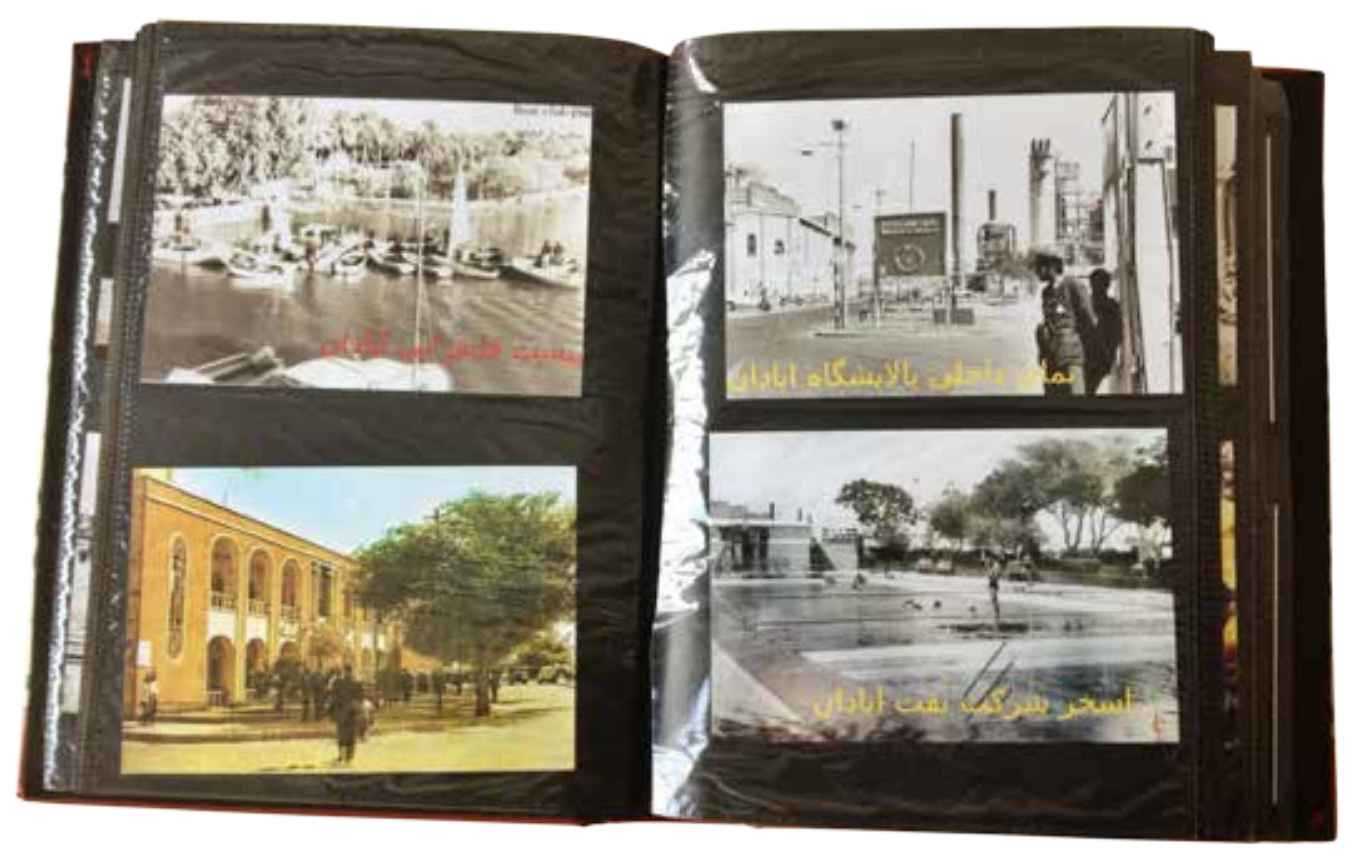

Fig. 2: Fotoalbum købt i Abadans basar, 2013. Billede taget af forfatteren.

sådan et album vil de også have! Nostalgien trives også hos de, der er for unge til at huske: For dem er fortiden et sted, de kun kender igennem historier og billeder men som ikke desto mindre er en kilde til stolthed. Selvom kaptajnen forsøger at få rabat på albummet, så er prisen ikke til forhandling. Nostalgibranchen har kronede dage i Abadans basarer.

Minderne og forestillingerne om fortiden har nærmest kultisk status i Abadan, og nostalgien legemliggøres i en række medier, symboler, fortællinger, tekster og objekter, der skal forbinde nutiden med fortiden, og som opbevares, produceres og reproduceres af almindelige abadanier. Det er især de lokale amatørhistorikere, der med nørdet entusiasme samler på fortidens genstande; fortrinsvis billeder, men også olieselskabets nyhedsbreve, plantegninger, personaledokumenter, uniformer, plakater, medaljer, selv madrationskuponer og skemaer med bustider. Hvis man først er til middag hos en ældre abadani og begynder at tale historie, så bliver der snart hevet rodekasser og anekdoter frem. Men også blandt yngre abadanier er der en stor interesse.

Abadanierne, der under krigen med Irak blev spredt for alle vinde, har således en stærk tilstedeværelse på internettets sociale medier. På Facebook findes den aktive gruppe 'Olieindustriens Børn', der publicerer billeder med dertil knyttede historier, som gruppens medlemmer, de fleste fra diasporaen, selv indsender. Der er snesevis af sådanne online forummer, weblogs og hjemmesider, essays og billedserier. Også i den virkelige verden samles abadanierne i foreninger og netværk, det være sig i Teheran, Los Angeles eller London. Der er også en sammenslutning for tidligere europæiske og amerikanske ansatte, The Abadan Society, 
der i nyhedsbreve udveksler minder, vittigheder og billeder fra medlemmernes tid i byen.

Nogle af de lokale entusiaster i Abadan har endog taget skridtet at udgive deres erindringer. Et eksempel er bogen Anglo og Bungalow i Abadan af Iraj Valizadeh, der udkom i 2010. Her springer fortællingen fra ét emne og format på den ene side til et andet på den næste, i noget, der minder om en distræt tankestrøm: Fra forfatterens personlige minder, der til tider genfortælles langs en geografisk rute i hans barndomskvarter, over til oversættelser af artikler fra selskabets engelske tidsskrift; fra detaljerede gennemgange af ingeniørtekniske tiltag i raffinaderiet til opskrifter på lokale madretter; fra minutiøse beskrivelser af bestemte bygningers arkitektur og historie til optegnelser over sportsudøveres rekorder og medaljer. Hele bogens narrativ hænger uløseligt sammen med olieindustrien, hvilket også er afspejlet på forsiden: Bag overskriften toner olietårnene frem, og under den er der billeder af tre af de britiske gentlemen, der grundlagde olieindustrien og det moderne Abadan, som nederst er repræsenteret ved et billede af pæne rækkehuse (fig. 3). Der er således en direkte forbindelse mellem olien, de kapitalistiske kræfter, der udvandt den, og den materielle velstand, den tilvejebragte lokalt.

Valizadeh lægger ingen skjul på sin længsel efter fortiden. Han forklarer at han efter at have læst en artikel i en iransk avis om det nuværende Abadans triste tilstand blev motiveret til at skrive sin egen bog. I stakåndet prosa fortæller han sin reaktion på artiklen:

„Jeg mindedes det vi kaldte livet, indenfor rammerne af særlige principper og regler, og byen Abadans kultur som blev skabt af mødet mellem briternes disciplin og de 72 Nationers særegenskaber, det vi kaldte Abadans samfund, hvor man langt fra al tilbageståenheden i andre byer lykkeligt og i ro kunne trække vejret, og jeg oplever det som blot en drøm, en drøm, der bevægede sig med lynets hastighed igennem hele mit liv, og jeg indser at livet i Abadan, med alle sine gode sider, kærlighed, varmblodighed, gæstfrihed, skønhed, fremgang og principfaste ordentlighed, ligesom i civiliserede nationers liv, hvad end det var, blot var en drøm, og jeg blev grebet af en trang til at fortælle om alt det, jeg havde hørt og set, rørt, lært og mistet, fra min fødsel til den dag, Overfaldskrigen tvang os væk, en trang til at fortælle denne historie under overskriften 'Abadan var en drøm'. “10

Valizadeh idylliserer fortiden samtidig med at han sætter spørgsmålstegn ved dens virkelighed: Var Abadan blot en drøm? Eller var Abadan som en drøm? Det er under alle omstændigheder en drøm, som mange abadanier vil huske og mindes om, fange i billeder og gemme i levn og historier - om de så er for unge

10 Valizadeh 2010: 32. De 72 Nationer er en standardvending i det persiske sprog, der henviser til verdens og/eller Irans etniske og kulturelle mangfoldighed, og Overfaldskrigen er den officielle term for Iran-Irakkrigen. 


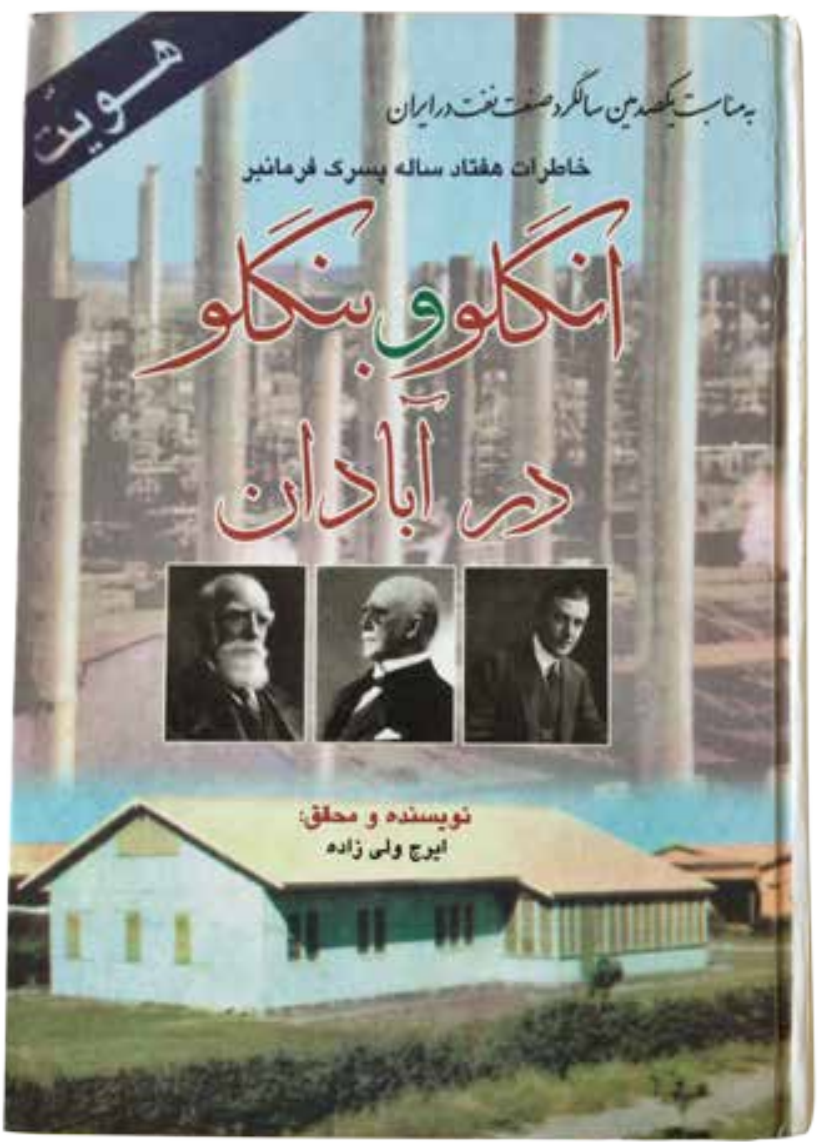

Fig. 3: Forside af Valizadeh 2010. Billede taget af forfatteren.

til at have oplevet drømmen selv, eller er gamle nok til at nedfælde den på skrift. Ligeså flygtig som denne drøm forekommer Valizadeh, ligeså nærværende er den i nostalgien.

\section{En ordentlig tid i rum}

Et omdrejningspunkt i Valizadehs beskrivelse af fortidens Abadan er orden, disciplin og trygge rammer. Disse rammer blev afstedkommet af olien og materialiseret i det samfund som olieselskabet institutionaliserede under briterne. Det er da også netop hvad man hører i det folkelige narrativ: Abadan var en ordentlig by, der nu er i uorden, ikke kun pga. revolution og krig, men også på grund af magthaverne, eliterne, ja faktisk også almene abadaniers egen fejlforvaltning og mishandling af byen. Med en tyk selvkritik bliver man som besøgende konstant mindet om at 'folk' ikke længere kan overholde regler, at de ingen respekt har for det offentlige rum og at byen har tabt sin æstetiske identitet. Indbyggerne kan eller vil ikke længere overholde retningslinjerne for hvordan boligerne, som selskabet i sin tid opførte, skal se ud, hvordan hække skal klippes, facader rengøres, biler parkeres osv. „Byen har mistet sit historiske udseende, og borgmesteren vil 
ikke gribe ind - det er simpelthen for besværligt at ændre mentaliteten“, fortæller en lokalpolitiker mig.

I nostalgibøgerne mindes forfatterne ofte raffinaderiets kæmpemæssige horn (feydus), der på skemalagte tidspunkter annoncerede at oliearbejderne skulle stemple ind eller ud. Disse horn var også med til at indføre en sans for tid udenfor raffinaderiet. De var en del af den orden og disciplin, der regulerede byens liv, og som mine informanter beklager i dag er forsvundet. Postvæsnet, lønudbetalinger, elektriciteten og frem for alt trafikken er i uorden. „Dengang gled trafikken let, og der lå ikke affald i gaderne“, siger en informant, uden at specificere hvilken tid han taler om. „Vi havde engang landets bedste kloakering“, siger en anden informant, der arbejder i en lille lokal bank. „I dag siver kloakaffaldet ind i boligerne. De grønne fællesarealer bliver ikke passet, der vokser ukrudt overalt og der er graffiti på væggene“, sukker bankmanden. I dag, mere end 25 år efter krigen, kan man stadig se skudhuller i nogle af Abadans bygninger.

I Valizadehs bog bliver byens nuværende tilstand kontrasteret med datidens orden igennem detaljerede beskrivelser af de velfærdsprojekter, selskabet i sin tid forestod. Der er således snesevis af sider i bogen, der udpensler hvordan briterne i tiden omkring 2. Verdenskrig indførte en række selvforsyningstiltag, der reddede Abadan fra hungersnød. Valizadeh gennemgår hvordan selskabet først opmålte landområder udenfor byen i yards og feet, inddelte dem i plots og efter komplicerede afsaltningsprocesser overdrog dem til lokale med klare retningslinjer for hvordan jorden skulle gødes og opdyrkes. Dernæst gennemførte selskabet folkeoptællinger for at kunne tildele familier rationskuponer, der kunne indløses i brugsforeninger. For at holde styr på gemytterne når iranerne flokkedes til disse nymodens butikker bad briterne folk om at sidde ned på fortovet. Og således lærte abadanierne, ifølge Valizadeh, ikke bare køkultur, men også samarbejde om fælles problemer i samfundet, at udnytte den svært opdyrkelige jord ved hjælp af teknologisk snilde og at omfordele udbyttet igennem systematiske foranstaltninger. Alt sammen, fornemmer man i bogen, takket være selskabets industrielle disciplin og de sociale rum, som oliebyen skabte. Denne disciplin og disse rum muliggjorde ikke bare oliens men også abadaniernes raffinering. Valizadeh er ikke blind for den skæve fordeling af goder i samfundet under briterne, men han udviser stor tiltro til den kultur, som briternes foretagsomhed og ordentlighed var med til at tilvejebringe.

Denne abadani kultur, fortæller nostalgibøgerne, har i dag lidt skade og samfundet har mistet den ordenssans som før var en kilde til stolthed. Kommunen beskyldes således for nepotisme og ineffektivitet. En lokalpolitiker gik ifølge bankmanden for nyligt til valg med sloganet „Vi vil ikke have fremskridt - vi vil tilbage til 20 år før revolutionen!“ - et slogan, der tydeligt strider imod den officielle retorik i den islamiske republik. Og nostalgien efter det moderne, som det så ud før revolutionen, kan da netop også tolkes som en kritik af staten, dens 
politik og ideologi. Dermed ikke sagt at nostalgibøgerne udelader de kilder til stolthed, som staten netop gerne vil fremhæve: Byens rolle i revolutionen og patriotiske forsvar mod Irak under krigen. Men i modsætning til det statslige narrativ placerer nogle af nostalgibøgerne Abadans storhedstid før snarere end under revolutionen og krigen. Oliens aftagende magi har ladt samfundet i stikken, og i nostalgien efter en ordentlig tid med ordentlige rum hænger Abadan utrygt suspenderet i sin egen historie.

\section{Fra centrum til periferi}

I gamle dage, fortæller mine informanter, var Abadan modernitetens centrum i Iran: En kosmopolitisk ledestjerne for Mellemøsten og et internationalt anerkendt punkt på verdenskortet. Det er netop også på et internationalt grundlag man kvantificerer Abadans fortid og kontrasterer med dens nutid. Abadan blev i folkemunde kaldt Lille London eller Det Andet London (landan-e sâni), og man hører ofte lokale fortælle om hvordan der fra Abadan var daglige, direkte fly til England, hvordan London Times blev leveret samme morgen som den udkom, hvordan biograferne havde premiere på film samtidig med britiske biografer og hvordan universitetet samarbejdede med Birmingham. Olien forbandt Abadan med resten af verden, og olien synkroniserede byen med det moderne vestens tid. I dag, hvor det meste af verden har glemt Abadan, er fortællinger om denne samtidighed og forbundethed stadig kilden til stolthed.

Den lokale stolthed tenderer til tider mod bevidst selvironisk overdrivelse eller lâf - et fænomen i abadani kultur som er genstand for mangen en joke i Iran. En abadani, der som mange af sine medborgere er stor fodboldfan, vil helst snakke med mig om Michael Laudrup og Peter Schmeichel, og hvorfor de aldrig kom til Abadan for at spille mod byens eget fodboldhold, San'at-e naft, „Olieindustrien“. Her kommer lâf i brug: „Inden det danske landshold nåede til Abadan ville vi have vundet kampen 3-0, siger jeg dig! De eneste vi måske ville spille uafgjort med er Brasilien!“. Sjovt nok identificerer abadanier deres by med netop Brasilien. En lokal forsker foreslår at det måske hænger sammen med tropeklimaet, palmerne og den varmblodige mentalitet. Mere nærliggende er dog at det lokale fodboldsholds farver er gul/grøn ligesom det brasilianske landsholds, og at man lokalt mener at holdet i modsætning til andre iranske hold spiller 'sambafodbold'. En populær vending på persisk er âbâdân berâzilet-e!, 'Abadan er dit Brasilien!' Associeringen med Brasilien understreger hvordan byen ser sig selv i en global snarere end blot iransk sammenhæng.

Den internationale, kosmopolitiske fortid kommer til udtryk på mange niveauer i hverdagen i Abadan. Der er talrige engelske låneord i abadani dialekt, men også ord fra hindi og punjabi. Mange af gaderne, der officielt er gendøbt med 
revolutionære og islamiske navne, kaldes stadig lanes i folkemunde - fx Sikh Lane, hvor indere engang boede. Abadans flotteste bygning, Burmesernes Moské, er bygget med inspiration fra indisk tempelarkitektur og under dens fine ornamenter gemmer sig en struktur sammenstøbt af aflagte olierørledninger. Den britisk-indiske fortid viser sig desuden i madkulturen, der adskiller sig væsentligt fra persisk mad ved at byde på stærke karryretter, chapati-brød, pakora-snacks osv. Der er kun to indiske restauranter tilbage i Abadan, men de er til gengæld også de mest populære. De fleste indere, jøder og kristne har for længst forladt byen, men de bliver ivrigt mindet af abadanierne i dag, i og udenfor Abadan. ${ }^{11}$

Den nostalgiske stolthed kredser især om den kulturelle smeltedigelskraft byen i sin tid besad. En lokal forsker sammenligner abadani identitet med ma'jun, en slags milkshake, der bl.a. indeholder bananer, honning, kokos, pistacienødder og dadler. På samme måde er abadanierne byens blandingsprodukt. „Jeg boede i en gade, hvor der var en libanesisk kristen araber, en indisk familie, en familie fra Bushehr, en fra Tabriz og en fra Dezful [byer i Iran, red.]. Vi levede side om side, uden problemer,“ fortæller forskeren, der ligesom mange andre abadanier hylder den stærke nabosolidaritet, der angiveligt prægede befolkningen før i tiden. Netop på grund af den multietniske sammensætning som olieindustrien tilvejebragte, og fordi mange iranere kunne bryde med deres traditionelle bånd til familier og stammer når de flyttede til Abadan, så opstod der en helt særlig identitetsfølelse. Selvom nogle etniske grupper flyttede sammen i bestemte gader og frekventerede deres egne moskéer, så knyttede de også bånd til andre i kvarteret. Olieselskabets byplanlægning bragte folk sammen på en måde, der affødte nye omgangsformer som adskilte sig kraftigt fra traditionelle iranske samfund. Denne særlige abadani kultur blev altså formet af oliens magiske kraft til at skabe nye rum og forvandle byen.

Abadan blev i 1950erne symbol for en amerikansk-inspireret materialisme, med dertilhørende fokus på udseende og image. Her importerede man for første gang luksusvarer, udenlandske biler, vaskemaskiner og airconditionanlæg til Iran. Abadanierne selv blev kendt for en særlig, nymodens tøjstil. Den allervigtigste genstand var solbrillerne, som er abadaniernes kendemærke - i så høj en grad at der er en hel genre af vittigheder på persisk, der handler om abadaniers forkærlighed for Ray-Bans. Men derudover var det vestligt tøj, Clarks sko, amerikanske jeans, engelske skjorter og fine hatte, der definerede abadani chik. Også udenfor Abadan bemærkede man sig trendsetterne fra syd. „Når vi tog til Mashhad [en by i det nordøstlige Iran, red.], så bad vennerne os om at købe nyt tøj med til dem“, fortæller bankmanden. En abadani gjorde meget ud af sin fremtoning og var storforbruger af parfumer og skønhedsprodukter hvilket også kan forklares med den

11 En af de mest populære nyere noveller på persisk er Zoya Pirzads Jeg slukker lysene, der beskriver forstadslivet blandt armensk-iranske familier i Abadan. Se Pirzad 2013. 
lugt og det snavs, arbejdet med og i den varme olieby kunne skabe. Kontrasten mellem den lokale traditionelle arabiske klædedragt og de moderne oliearbejderes elegante fyraftensbeklædning kunne ikke være større. Men selv raffinaderiarbejdernes kedeldragter og sikkerhedshjelme fremhæves på abadani hjemmesider som kendetegn for byens moderne profil.

I nostalgibøgerne er der detaljerede gennemgange af byens mange muligheder for fritid og forlystelse: der var spejderklubber, syklubber og madlavnings- og hygiejnekurser; der var golf, brydning og hesteløb; der var svømmekonkurrencer, en rulleskøjtehal og backgammon på caféerne; der var ikke bare nogle af Irans første biografer, men hele 15 af dem da revolutionen brød ud; og der var selvfølgelig også den slags forlystelser, som man kun med afstandstagen og selvcensur kan skrive og tale om i Iran i dag, nemlig barer, natklubber, kabaretter, opiumshuler og bordeller. Trods segregering mellem vesterlændinge og iranere så var Abadan i sin tid - og især i nutidens nostalgiske fremstillinger - kendt som en frisindet, fordomsfri og hedonistisk storby. Mange iranere så op til Abadan: En ansættelse i olieselskabet var et drømmejob og byen var et yndet rejsemål for indenrigsturister - „også selvom vi jo ikke har nogen seværdigheder“, fortæller bankmanden. Abadans tiltrækningskraft bestod i de forestillinger om byen og dens befolkning, som olien fremkaldte.

Iranere betegner stadig abadanierne som tilbagelænede, morsomme, åbne og lidenskabelige, og byens ungdomsliv forekommer stadig i dag mindre forstokket og behersket end de omkringliggende byers. Ikke desto mindre klager nogle abadanier over, at krigens socioøkonomiske omvæltninger har afstedkommet en voksende konservativ traditionalisme i byen. I stedet for den kulturelle og politiske diversitet, der kendetegnede byen før revolutionen er den arabiske stammepolitik blevet genoplivet. ${ }^{12}$ Ifølge nogle kritikere, herunder lokalpolitikeren, jeg interviewede, har dette medført en mere provinsiel kultur end fortidens kosmopolitisme. Det er som om oliens stagnation og raffinaderiets reducerede rolle i byen opfattes som direkte årsag til en kulturel afmatning. Nostalgien hylder den tid, hvor Abadan sprudlede kulturelt, stod centralt placeret i verden og var synkroniseret med vesten: En trendsetter, der er nu er gået af mode og gledet ud i periferien.

\section{Vand og rust}

Et særligt klagepunkt for mange af Abadans indbyggere i dag er, at byen ikke længere står for det sunde og opbyggelige miljø, den engang gjorde. Dele af ungdommen bærer tydeligt præg af desillusion, arbejdsløshed og narkotikamisbrug. „De unge dyrker ikke længere sport. Vi plejede at have de bedste sportsmænd i landet, 
men nu driver de arbejdsløse rundt i gaderne hele natten og tager stoffer“, siger bankmanden. Ikke kun det sociale men også det fysiske miljø figurerer centralt i nostalgibøgerne. I hele Khuzestan-provinsen er drikkevandet i dag af alarmerende dårlig kvalitet, og regionen er præget af forurening fra metal-, sukkerrørsog petrokemikalie-industrien. Hovedstaden Ahwaz besidder ifølge WHO den tvivlsomme ære at have den mest forurenede luft af alle verdens millionbyer. ${ }^{13}$ Provinsens indbyggere lider under en lang række sygdomme forårsaget af forureningen og har en af Irans laveste gennemsnitlige levealdre. Tørke, tilsaltning og dårlig forvaltning har ødelagt landbruget. Efter at floder i Tyrkiet og Iran er blevet opdæmmede og sumpene i Sydirak tørlagt er hele regionen blevet forvandlet til én stor støvskål. Ofte bliver Abadan nærmest kvalt i sandstorme.

Adgang til drikkevand, vandets kvalitet og vandets symbolske betydning i et ørkensamfund spiller således en særlig rolle i nostalgibøgerne, der ofte indeholder oder til floderne omkring byen; eller - som i Valizadehs tilfælde - detaljerede gennemgange af hvordan olieselskabet indførte drikkevandssystemer, vandrensningsanlæg og svømmebassiner i byen. Men ikke alle nostalgibøgerne idylliserer olieselskabets og briternes velgørenhed. Et eksempel er Ali Farrokhmehrs bog Abadan: De Godes Jord, Mindet om Vennerne. Farrokhmehr fremhæver fra begyndelsen af bogen vandets rolle i Abadan, men i modsætning til Valizadeh hylder han bestemt ikke briterne. Han forklarer hvordan selskabet i 1940erne gravede en kanal fra Bahmanshir-floden ind til et af de nye kvarterer, som gav vand til haver og til et stort offentligt svømmebassin. Han mindes at lege i vandet og nyde haverne men tager også afstand fra dette spektakel, som i virkeligheden var del af en pr-strategi, der skulle dække over byens uligheder:

„Alle selskabets kvarterer havde drikkevand, el og asfaltering, men resten af byen var frataget alle livets nødvendigheder! Abadan var uløseligt forbundet med modsætninger. Ved siden af verdens største raffinaderi trivedes kummerligheden. En klump is var noget man drømte om! I skyggen af raffinaderiet var lurer, kurdere, arabere, baluchier og perseres eneste fritidsfornøjelse en svømmepøl og Bahmanshir-biografen under åben himmel! Summen af alle disse modsætninger gjorde Abadan til en by på nippet til en eksplosion!“14

I modsætning til Valizadeh er Farrokhmehr opvokset i slumkvarteret Ahmadabad, og hans udlægning af fortiden er at ,ethvert sted, der har blomster, har også torne!“. Denne udlægning ligger tættere op ad det officielle statslige narrativ, der på én gang hylder oliens magiske kraft til at modernisere og samtidigt 
kritiserer oliekapitalismens grundlag i vestlig imperialisme. ${ }^{15}$ For Farrokhmehr er det mindeværdige ved Abadans fortid en kultur, der nok tog udspring i de af olieindustrien skabte rammer, men som var umiskendeligt iransk, patriotisk og religiøs. Hans minder kredser således om de iranere, der som boghandlere, folkeskolelærere, digtere, sportsudøvere og ingeniører var med til at skabe Abadan. Farrokhmehrs Abadan er de undertrykte, de troende, de revolutionære og martyrernes by, en historisk skueplads for vestens modstand mod Irans industrielle fremgang og ideologiske udvikling. Abadan er i denne udlægning produktet af en påtvunget vestlig modernitet, der gradvist blev approprieret af iranerne og omformet til en indfødt modernitet. Da det var lykkedes iranerne at overtage olien - og Abadan - så hævnede imperialisterne sig ved ødelægge byen, nu med hjælp fra vestens håndlanger Saddam. Farrokhmehr afviser derfor, at hans længsel er en forherligelse af fortiden:

„Hvorfor, med alle disse skuffelser og al den smerte, kredser hjerterne stadig om de gamle dage? I ethvert hjørne af Iran bringer midaldrende, ældre og oldinge mindet om de gamle dage til live med et suk. Et suk, ikke af had til nutiden, men fordi dagene passerer flygtigt og livet er kort ... Ja, det var skam olien, der gjorde 'Abbâdân [byens gamle arabiske navn] til Abadan [byens nutidige navn, der er beslægtet med ordet for „fremgang“ og „opblomstring“]. Ja, det var skam opførslen af raffinaderiet, der gjorde Abadan til en by! Olien, raffinaderiet, Arvand Rud-floden, Bahmanshir-floden, pengene, havnen, eksporten og importen, der gjorde en ø til en blomstrende havn. Med tiden, langsomt, med en skildpaddes hastighed. Men med al den rigdom kunne den også have blomstret endnu mere end den gjorde!“16

Farrokhmehr lader altså til ikke at være nostalgisk over fortidens storhed men over fortidens forpassede fremtider: Snarere end en idyllisering af fortidens pragt udtrykker han en skuffelse over at byen ikke blev alt det, den kunne have været - i kraft af olien. Han hylder oliens evne til at gøre iranerne uafhængige af vestlig imperialisme men begræder også oliemiraklets omkostninger. I denne skuffelse ligger der også en subtil kritik af de post-revolutionære magthavere i Iran. Som han skriver i en anden bog, Abadan: Godhedens Gyder:

„Den lange krig, livet som fordrevet og i eksil, løfter og forjættelser, hverken krig eller fred; og så småt mistede Abadan sin værdi og værdighed, og befolkningen blev trøstesløse og deres hjerter kolde. Man glemte den kunstige sø og svømme-

15 Et eksempel på dette er Abadan Kommunes turistbrochure der blev udgivet i forbindelse med det iranske nytår 2011/2012 hvori krigen og dens martyrer er omdrejningspunktet for en narrativ om Abadan som symbolet på anti-imperialistisk modstand.

16 Farrokhmehr 2011: 109-110. 
bassinet. Rørledningerne i jorden rustede til. Haverne falmede og Tank 1 og Tank 2 [bydele i Abadan] blev værre end slumkvarterer med blikskure! ... Dette er ikke kun historien om vand og tørke. Det er historien om en bys afvikling. “17

Farrokhmehrs fortælling handler altså delvist om frustrationen over uindfriede løfter om genopbygning efter krigen og magthavernes ligegyldighed. Dermed indskriver Farrokhmehrs fortælling sig i en skuffelse, som præger mange troende og konservative, især i Irans lavere klasser, der havde håbet, at revolutionen ville bringe social retfærdighed og velstand, men i dag er frustrerede og uforløste. Farrokhmehrs nostalgibøger adskiller sig fra Valizadehs ved ikke at forherlige olieselskabet, og især ikke briterne. De er således tættere på den statslige narrativ om byen, men adskiller sig alligevel ved at være kritiske. Nostalgien i Farrokhmehrs bøger slår ned i det paradoksale ved det moderne i Abadan: Trøsteløsheden ved livet i en by, der er omringet af floder men ikke engang har rent drikkevand; skuffelsen over livet i en by, der med olien fik et potentiale til at forvandle sig selv til et mirakel, men så blev frarøvet sit mirakel af nidkære fremmede magter. Som et symbol på uretfærdighed er oliens fravær konstant tilstede i Farrokhmehrs historier om afviklingen af en by, der blev født af olie - og næsten døde på grund af olie.

\section{Sidste akt}

Biografer fremstår centralt i Abadan-nostalgiens erindringsgeografi som symbol på de vinduer til verden, som olien åbnede i byen. Selskabet indførte i 1912 den første transportable projektor for at vise film udelukkende for briterne men indså hurtigt, at filmmediet havde en praktisk værdi. Man byggede efterfølgende en række biografer, under åben himmel, i nedlagte lagerhaller eller i nye bygninger. Her viste man propagandistiske nyheder fra England og reklamer for selskabet, og man producerede sågar en film om Abadan, Persian Story, der skulle overbevise abadanier, iranere, briter og alle andre om oliens magiske kraft, om selskabets velgørenhed og om Abadan som indbegrebet af moderne fremskridt. ${ }^{18}$

Men med tiden kom også privatejede biografer til, heriblandt Irans største og teknisk mest avancerede. Nogle biografer viste vestlige film, og nostalgibøgerne overleverer minder om Tarzan, Hopalong Cassidy og Øst for Paradis. Andre biografer viste indiske Bollywood dramaer med dans og farver eller romantiske film fra Ægypten. Takket være Abadans relative uafhængighed fra Teheran og dermed statens censur kunne biograferne også vise ubeskårede samfundskritiske 


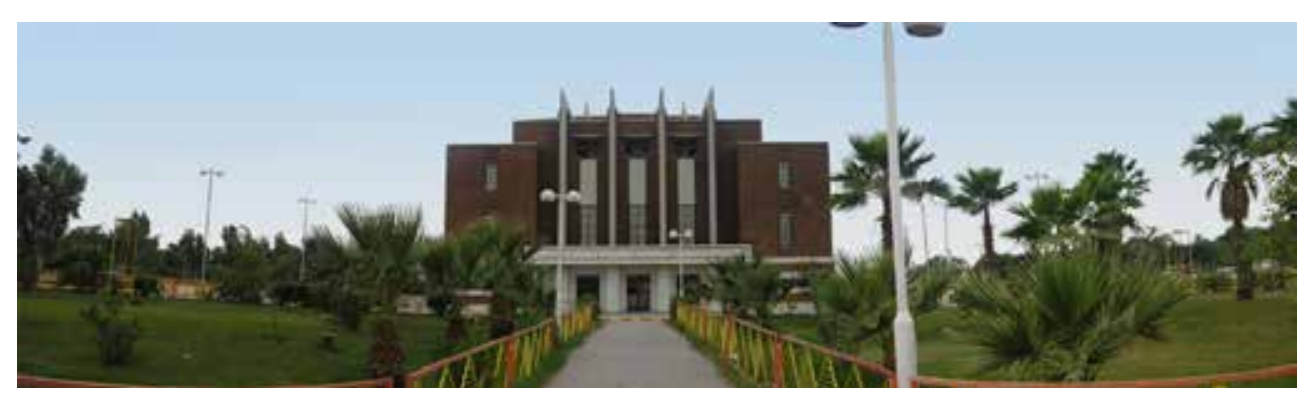

Fig. 4: Cinema Taj, Abadan. Kilde: http://commons.wikimedia.org/wiki/ Category:Abadan\#mediaviewer/File:Tajcinema.jpg - anvendt under GNU licens: http://commons.wikimedia.org/wiki/Commons:GNU_Free_Documentation_License

film fra Iran samt stribevis af gangsterfilm og lumre komedier med mavedanserinder. Fra hele regionen trak biograferne folk til Abadan: Arabiske stammefolk kom sejlende i joller fra Irak eller ridende fra palmelundene ind til Abadan for at se Abdel Halim Hafez, Den Mørklødede Nattergal fra Cairo synge om sit knuste hjerte, eller Charlton Heston i hæsblæsende ræs mod sejr i Ben Hur. En biograftur kunne være en picnic for hele familien eller en mulighed for i smug at kysse med kæresten. Biografgængerne sang med, græd og hujede, og der kunne udbryde tumulter, hvis forevisningen blev afbrudt. Abadan var besat af film, og biograferne var byens vartegn: Et af de mest populære postkort fra Abadan viser Cinema Taj, bygget med røde mursten importeret fra England (fig. 4). Men denne ihukommelse af biografernes Abadan indebærer måske også en glemsel: Den sidste akt i fortællingen om Abadans storhedstid fandt for mange abadanier nemlig også sted i biografen.

Den skæbnesvangre, glohede aften den 19. august 1978 hvor over 500 abadanier brændte ihjel i Cinema Rex var det filmen Gavazn-hâ (,Hjortene“), der havde trukket fulde huse. Det tillægges i dag stor betydning, at det var netop denne film, der var på lærredet netop denne aften. Gavazn-hâ, en filmklassiker af Masud Kimiai, fortæller om Qodrat, en bankrøver på flugt, der søger ly hos en barndomsven, narkomanen Seyyed og dennes kæreste, der arbejder i de lurvede kabaretter i Teherans red light district. Med Qodrats hjælp lykkes det Seyyed at knække sit misbrug, forsvare kærestens ære og stå fast overfor sine rivaler. Med sin benhårde fremstilling af modernitetens skyggesider kom filmen kun med stort besvær igennem censurens nåleøje og blev modtaget af mange iranere som en overført kritik af shahens regime. Det er også med afsæt i denne forståelse, at den islamiske republik i dag forsøger at give mening til branden i Cinema Rex, der netop brød ud imens slutscenen i Gavazn-hâ blev vist: At shahen ville bremse det ulmende oprør, symboliseret ved filmen, og skyde skylden for branden på islamistiske radikale, når det i virkeligheden var shahens egne folk, der stod bag ildspåsættelsen (fig. 5). 


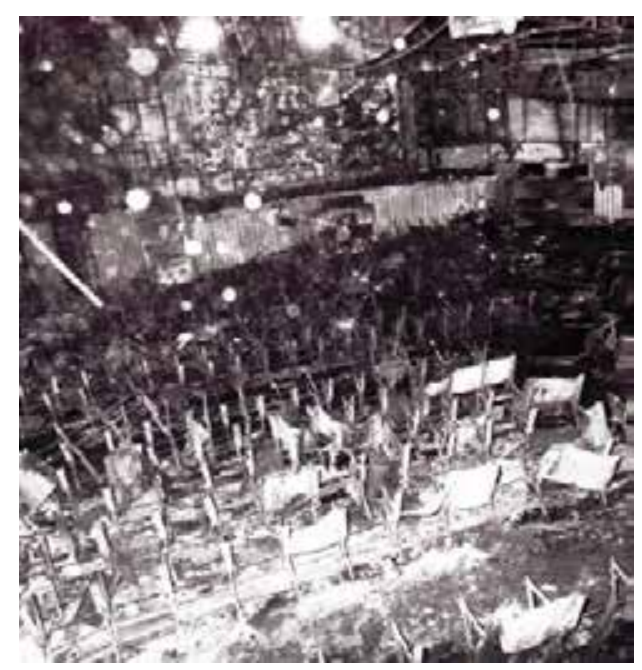

Fig. 5: Billede fra Cinema Rex efter branden. Kilde: http://commons.wikimedia. org/wiki/Category:Abadan\#mediaviewer/ File:CinemaRexFire.jpg

Den modsatte udlægning, der stadig trives blandt mange iranere, går ud på, at islamister ville slå to fluer med ét smæk: Skyde skylden på shahens efterretningstjeneste og ramme et mål, der for mange islamister var indbegrebet af synd og vestlig dekadence, nemlig biografen. Biografen var som et moderne rum symbol på materielt fremskridt, en nymodens populærkultur og en inspiration for mange unge iranere; men den blev med tiden også opfattet af nogle som et symbol på moralsk forfald og vildledning. Lige meget hvilken udlægning man hælder til, så hænger nostalgien efter biografernes Abadan tæt sammen med modernitetens smertelige selvmodsigelser og med det uindfriede løfte om en strålende fremtid, der i oliebyen gik op i flammer: Først i Cinema Rex-branden, og to år senere i Iran-Irakkrigen. Slutscenen i historien om Abadans storhed starter med en brand og ender med en krig.

I modsætning til den stats-sponsorerede martyrsymbolik, der dyrkes i en omfattende kulturindustri og som fremstiller den patriotiske kamp mod Irak som startpunktet for en ny æra i Irans historie, så stopper de fleste nostalgibøger fortællingen ved krigens udbrud. Dette hænger naturligt sammen med byens evakuering: Mange abadaniers minder fra byen stopper med den tragiske historie om at flygte fra hus og hjem, at bo i flygtningelejre, at flytte til andre byer eller at udvandre fra Iran. Krigen nulstiller Abadans historiske ur. Det er som om at de nostalgikere, der stadig er i Abadan i dag, lever i de falmede kulisser af det, der engang var en prægtig og banebrydende film, men som viste sig ikke at have en lykkelig afslutning. Olien gik fra at være en kilde til velstand og fremgang til at være en årsag til modgang, ødelæggelse og fordrivelse og nu, en baggrund for stilstand. Men olien forbliver en vedvarende kilde til nostalgi, kritik og selvkritik, selvopfattelse og stolthed. 


\section{Konklusion: Når strømmen går i Abadan}

„Vores raffinaderi var verdens største, og det er stadigvæk stort - men ikke desto mindre har vi strømafbrydelser hver dag; det kan simpelthen ikke passe“, siger en informant. Og som besøgende undrer man sig da også over hvordan ét af verdens olierigeste steder, stadig med et døgndrevet raffinaderi, ikke kan levere noget så simpelt som vedvarende strømforsyning?

Abadan har på meget kort tid oplevet en række dramatiske, bratte afbrydelser i sin udvikling. Det er på baggrund af denne diskontinuitet, at nostalgien i dag dyrkes i Abadan: En kim lagt af pionerer, der med lynets hast fremkaldte en frodig oase, efterfulgt af en lang opblomstring og så en pludselig ødelæggelse, der efterlod byen som et fatamorgana suspenderet i tid. Ihukommelsen af denne historie og dens nostalgiske genfortælling er vævet sammen med oliens magiske kraft. Modernitetens muligheder lå fysisk materialiseret i gigantiske, beundringsværdige metalliske konstruktioner midt i byen, og bebudede velfærd, fremgang og lykke. Olien åbnede for nye horisonter og gjorde at abadanierne kunne opfatte dem selv og deres by i en global sammenhæng. Olien var drivkraften bag og smøremidlet i økonomien og byudviklingen ligesom den var i folks drømme og håb til fremtiden, og i deres sociale omgangsformer og kulturelle verdener.

Abadanierne tager ofte selv afstand til idylliseringen af fortiden: Ved at fremstille minderne som „en drøm“, ved at smøre tyk lâf ironi på stoltheden eller ved at huske os på de grumme, uretfærdige sider af historien. Det 'hjem', man søger i Abadans nostalgibøger er en særlig bykultur og kulturby, og 'længslen' er i sig selv en kulturel udtryksform. Heri adskiller Abadan sig ikke fra mange andre samfund i verden - parallellen kan hives hjem med et besøg på Facebooksiden Gamle København, der med sine daglige publiceringer af billeder fra 'barndommens gyder' nyder stor popularitet blandt danskere i alle aldre. ${ }^{19}$ I Iran er nostalgien også en kunstform, der dyrkes i poesien, og i populærkulturen henviser begrebet ghorbat til en fremmedgørelse i tid og rum, som fx i den iranske diasporas længsel efter hjemlandet eller efter storhedstiden under shahen.

Det, der imidlertid særtegner Abadans nostalgi, er olien. Olien skaber de dikotomier, hvorigennem nostalgibøgerne gendanner historien: Oliens tilstedeværelse skabte orden, og dens fravær bragte uorden; olien skænkede Abadan prestige før byen gik i glemmebogen; olien tilvejebragte en kosmopolitisme, der i dag er overtaget af provinsialisme; olien bragte strøm til gadebelysning overalt i verden men kan i dag dårligt forsyne Abadan selv; olien bragte sundhed, drikkevand og landbrug, der i dag er erstattet med forurening, rust og tørke; oliens magiske kraft gav liv til forestillingsevner, indtil biografen og de andre rum som stimulerede disse forestillinger brændte, lukkede og forsvandt. Den diskontinuitet og sus- 
pendering i tid, som nostalgibøgerne fremhæver, bryder altså med en teleologisk opfattelse af modernitet som et resultat af en modernisering, der følger en jævn bane. Nostalgien bygger på en logik, der på én gang hylder oliens evne til at skabe imens den erkender oliens tendens til at ødelægge.

Måske kan vi visualisere abadani identitet som ma jun-milkshaken, som forskeren foreslog, men en mere nærliggende metafor her er olien. Ligesom olien gennemgår en bearbejdning og raffinering inden den udskibes, så er Abadans folk og kultur også et blandingsprodukt forarbejdet af oliens magiske kraft - resultatet af sociale, økonomiske og politiske processer med ét klart formål, nemlig olieoutput, men med en lang række uforudsete biprodukter og bivirkninger. Olien flød igennem Abadans årer, og de strukturer og aktører, der skulle regulere gennemstrømningen var med til at skabe divergenser og lækager, der trods selskabets forsøg på social inddæmning og politisk kontrol affødte kreativitet, aktivisme og kultur. Billedsprog er der nok af, men nostalgibøgerne tager fat om metaforerne som konkrete elementer, der håndgribeliggør det paradoksale ved det moderne.

Abadanierne har mange grunde til at mindes fortiden, enten for at forsvare og forklare eller for at kritisere og begræde de omvæltninger, der knækkede Abadans fremdrift; eller for at glemme omvæltningerne og drømme sig væk til en anderledes fremtid, der kunne have været. Nostalgien kan altså ikke kun koges ned til en sekulær eller progressiv kritik af den islamiske republik, konservatismen eller den økonomiske deroute, selvom disse er vigtige komponenter i dele af nostalgikulturen. Det, der forener nostalgien, er de forventninger til og oplevelser med det moderne, som olien satte i værk. Når Abadan rammes af strømsvigt er det således kun olietårnenes flammer, der oplyser mørket, og det tydeliggør for enhver det skrøbelige, selvmodsigende og ultimativt flygtige ved det moderne. Nostalgien spiller ind i selvopfattelser og offentlig diskussion, hvormed almindelige mennesker forsøger at analysere og give mening til deres skæbner i en tid, hvor en ressource som olie skaber, former og fortryller nationer, samfund, byer og individer - og ødelægger dem.

\section{LITTERATUR}

Alissa, Reem. 2013. „The Oil Town of Ahmadi since 1946: From Colonial Town to Nostalgic City“. Comparative Studies of South Asia, Africa and the Middle East 2013: 33, s. 41-58.

Bayat, Kaveh 2007: „With or Without Workers in Reza Shah's Iran: Abadan, May 1929“. Touraj Atabaki (red.): The State and the Subaltern: Modernization, Society and the State in Turkey and Iran, I.B. Tauris. 
Boym, Svetlana 2007: „Nostalgia and Its Discontents“. Hedgehog Review 2007: 9, s. 7-18.

Coronil, Fernando 1997: The Magical State: Nature, Money, and Modernity in Venezuela, Chicago University Press.

Crinson, Mark 1997: „Abadan: Planning and Architecture under the Anglo-Iranian Oil Company“. Planning Perspectives 1997:12, s. 341-59.

Cronin, Stephanie 2010: „Popular Politics, the New State and the Birth of the Iranian Working Class: the 1929 Abadan Oil Refinery Strike“. Middle Eastern Studies 2010: 46, s. 699-732.

Damluji, Mona 2013: „The Oil City in Focus: The Cinematic Spaces of Abadan in the Anglo-Iranian Oil Company's Persian Story“. Comparative Studies of South Asia, Africa and the Middle East 2013: 33, s. 75-88.

Davis, Eric \& Gavrielides, Nicolas 1991: Statecraft in the Middle East: Oil, Historical Memory and Popular Culture, University Press of Florida.

Davis, Fred 1979: Yearning for Yesterday: A Sociology of Nostalgia, Free Press. Dinius, Oliver J. \& Vergara, Angela 2011. Company Towns in the Americas: Landscape, Power and Working-Class Communities, University of Georgia Press.

Ehsani, Kaveh 2003: „Social Engineering and the Contradictions of Modernization in Khuzestan's Company Towns: A Look at Abadan and Masjed-Soleyman“. International Review of Social History 2003: 48, s. 361-399.

Elling, Rasmus Christian 2013. Minorities in Iran: Nationalism and Ethnicity after Khomeini, Palgrave Macmillan.

Elling, Rasmus Christian 2015a: „On Lines and Fences: Labour, Community and Violence in an Oil City“. Ulrike Freitag et al (red.): Urban Violence in the Middle East...

Elling, Rasmus Christian 2015b: „A War of Clubs: Inter-Ethnic Violence and the 1946 Oil Strike in Abadan“. Nelida Fuccaro (red.): Violence and the City...

Farrokhmehr, Ali. 2001. Âbâdân: Kuche-hâ-ye mehrabâni [Abadan: Godhedens Gyder], Teheran: Nashr-e Abed.

Farrokhmehr, Ali. 2011. Âbâdân: Khâk-e khubân, yâd-e yârân [Abadan: De Godes Jord, Mindet om Vennerne], Teheran: Najaba.

Ferguson, James 1999: Expectations of Modernity: Myths and Meanings of Urban Life on the Zambian Copperbelt, University of California Press.

Freitag, Ulrike et al (red.) 2015: Urban Violence in the Middle East: Changing Cityscapes in the Transition from Empire to Nation State, Berghahn Books.

Fuccaro, Nelida 2013a: „Introduction: Histories of Oil and Urban Modernity“. Comparative Studies of South Asia, Africa and the Middle East 2013: 33, s. 2-6.

Fuccaro, Nelida 2013b: „Shaping the Urban Life of Oil in Bahrain: Consumerism, Leisure, and Public Communication in Manama and in the Oil Camps, 
1932-1960s“. Comparative Studies of South Asia, Africa and the Middle East 2013: 33, s. 59-74.

Fuccaro, Nelida 2015: Violence and the City in the Modern Middle East, Stanford University Press.

Gross, David 2000: Lost Time: On Remembering and Forgetting in Late Modern Culture, University of Massachusetts Press.

King, Ritchie \& Kuo, Lily 2013. „Here are the world's worst cities for air pollution, and they're not the ones you'd expect“, Quartz (www.qz.com).

Limbert, Mandana 2010: In the Time of Oil: Piety, Memory, and Social Life in an Omani Town, Stanford University Press.

Mitchell, Timothy 2011: Carbon Democracy: Political Power in the Age of Oil, Verso.

Pirzad, Zoya 2013: Things We Left Unsaid, oversat af F. D. Lewis, Oneworld Publications.

Salas, Miguel Tinker 2009: The Enduring Legacy: Oil, Culture and Society in Venezuela, Duke University Press.

Valizadeh, Iraj. 2010. Anglo va bangolo dar âbâdân [Anglo og Bungalow i Abadan], Teheran: Simia Honar.

Vitalis, Robert 2007: America's Kingdom: Mythmaking and the Saudi Oil Frontier, Stanford University Press.

Watts, Michael 2001: „Petro-Violence: Community, Extraction and the Political Ecology of a Mythic Commodity“. Nancy Lee Peluso \& Michael Watts (red.): Violent Environments, Cornell University Press, s. 189-212.

\section{English Summary}

We are often told that the presence of oil is a blessing clad as a curse, bringing wealth to a chosen few and misery to many. What is black gold to the elites is the 'devil's excrement' to the majority. Oil pollutes, breeds violence and corruption, nurtures dictatorship and chokes democratic development. To complicate this well-known story, this article focusses on the unique modern urban society, formed by the oil that brought to life the city of Abadan in the middle of the Iranian desert in the $20^{\text {th }}$ century. How do people of Abadan nostalgically recall the blossoming era, and how does this nostalgia tie in with the „magical power“ of oil? 